Click www.researchjournal.co.in/online/subdetail.html to purchase.

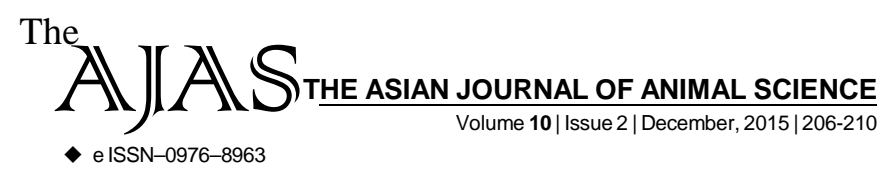

DOI : 10.15740/HAS/TAJAS/10.2/206-210
Visit us | www.researchjournal.co.in

RESEARCH ARTICLE.

\title{
Rural women access to inputs and markets in dairy farming
}

ANIKA MALIK, GAUTAM AND KAMALDEEP

Author for Corresponding -

ANIKA MALIK

Department of Veterinary and

Animal Husbandry Extension

Education, College of Veterinary

Sciences, Lala Lajpat Rai

University of Veterinary and

Animal Sciences, HISAR

(HARYANA) INDIA

Email: anikadhundwal@gmail.com

See end of the article for

Coopted authors'
ABSTRACT...... Livestock is generally considered a key asset for rural livelihoods. Rural women access to inputs and markets are considered as main pillars of women empowerment in dairy sector. The study was conducted in Hisar district of Haryana state with a sample size of 120 rural women engaged in dairy farming. Almost half of the respondents felt that they could ensure routine supplies like green fodder, compound feed, utensil and equipments etc. But in case of ensuring breeding services and purchasing new animal, a large majority was not confident. The respondents appeared constrained to utilize the growing market opportunities even if it is assumed that women can freely practice animal husbandry thus, raising doubts on the empowerment potential. There is need to revisit the idea of gender empowerment through livestock.

KEY WORDS....... Livestock, Rural women, Empowerment, Inputs, Market

HOW TO CITE THIS ARTICLE - Malik, Anika, Gautam and Kamaldeep (2015). Rural women access to inputs and markets in dairy farming. Asian J. Animal Sci., 10(2): 206-210.

ARTICLE CHRONICLE - Received : 13.05.2015; Revised : 20.11.15 Accepted : 26.11.2015 